\title{
A Simple Approach to Setting ReAsonable Royalties For STANDARD-ESSENTIAL PATENTS
}

\author{
Mark A. Lemleyt \& Carl Shapirot
}

\begin{abstract}
A Standard Setting Organization ("SSO") typically requires its members to license any standard-essential patents on fair, reasonable, and non-discriminatory ("FRAND") terms. Unfortunately, numerous high-stakes disputes have recently broken out over just what these "FRAND commitments" mean and how and where to enforce them. We propose a simple, practical set of rules regarding patents that SSOs can adopt to achieve the goals of FRAND commitments far more efficiently with far less litigation. Under our proposed approach, if a standard-essential patent owner and an implementer of the standard cannot agree on licensing terms, the standard-essential patent owner is obligated to enter into binding baseball-style (or "final offer") arbitration with any willing licensee to determine the royalty rate. This obligation may be conditioned on the implementer making a reciprocal FRAND commitment for any standard-essential patents it owns that read on the same standard. If the implementer is unwilling to enter into binding arbitration, the standard-essential patent owner's FRAND commitment not to go to court to enforce its standard-essential patents against that party is discharged. We explain how our proposed FRAND regime would work in practice. Many of the disputes currently arising around FRAND commitments become moot under our approach.
\end{abstract}

(C) 2013 Mark A. Lemley \& Carl Shapiro.

† Lemley is the William H. Neukom Professor at Stanford Law School and a partner at Durie Tangri LLP. Lemley has represented Google in matters related to the subject of this Article, but Google has provided no financial support for this project and the views offered here have neither been reviewed nor approved by Google.

H Shapiro is the Transamerica Professor of Business Strategy at the Haas School of Business, University of California at Berkeley and a Senior Consultant at Charles River Associates.

We speak only for ourselves. We thank Robert Barr, Jorge Contreras, Thomas Cotter, Joseph Farrell, Richard Gilbert, Rose Hagan, Robert Harris, Brian Love, Gil Ohana, Fiona Scott-Morton, Greg Sidak, Jeffrey Wilder, and participants at a workshop at the Federal Trade Commission for helpful comments on an earlier draft. 


\section{TABLE OF CONTENTS}

I. PROPOSED APPROACH TO FRAND COMMITMENTS 1139

A. BASIC STRUCTURE OF THE FRAND REGIME ………….................. 1140

B. WHAT HAPPENS WHEN NEGOTIATIONS FAIL? ................................. 1142

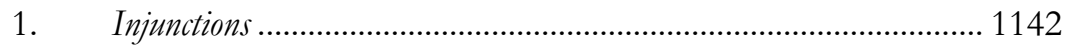

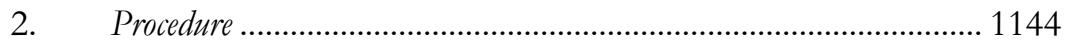

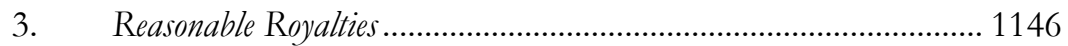

C. THE BOUNDARIES OF THE FRAND ARBITRATION......................... 1152

1. Unwilling Patentees and Unwilling Licensees................................... 1152

2. Essential vs. Non-Essential Patents.................................................. 1153

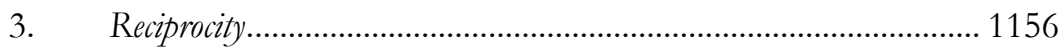

4. Transfer of Standard-Essential Patents ........................................... 1158

II. SIMPLIFYING THE FRAND DEBATES ……..................................... 1160

A. BREACH OF FRAND COMMITMENT................................................ 1160

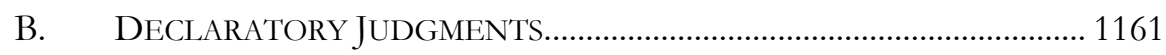

C. CONFLICT BETWEEN JURISDICTIONS ................................................. 1163

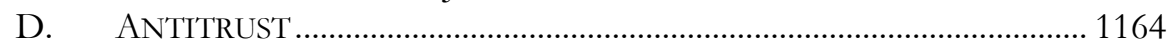

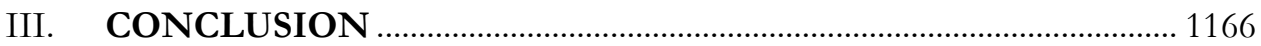

Voluntary standard-setting organizations enable industry participants to meet and establish technical standards. These standards can greatly facilitate competition and innovation. ${ }^{1}$ For example, the Institute of Electrical and Electronics Engineers ("IEEE") has established Ethernet and Wi-Fi standards. ${ }^{2}$ However, complications arise when implementing a standard requires practicing certain patents. Patents covering technology necessary to comply with a standard are "standard-essential patents."

The vast majority of standard-setting organizations ("SSOs") require their members to commit to license any standard-essential patents on fair,

1. See U.S. Dep’t of Justice \& Fed. Trade Comm’n, Antitrust Enforcement And Intellectual Property Rights: Promoting InNOVATION AND COMPetition 33-56 (2007), available at http://www.justice.gov/atr/public/hearings/ip/222655.pdf.

2. For more information about the 802.3 series of Ethernet standards, see IEEE 802.3: Ethernet, IEEE STANDARDS ASs'N, http://standards.ieee.org/about/get/802/ 802.3.html (last visited Mar. 30, 2013). For information about the 802.11 series of WiFi standards, see IEEE 802.11: Wireless LANs, IEEE STANDARDS Ass'N, http://standards.ieee.org/about/get/802/802.11.html (last visited Mar. 30, 2013). 
reasonable, and non-discriminatory ("FRAND") terms. ${ }^{3}$ These FRAND commitments serve two primary goals: (1) to promote the standard by assuring companies implementing the standard that they will not be blocked from bringing their products to market or held up so long as they are willing to pay reasonable royalties for any standard-essential patents, and (2) to provide reasonable rewards to those who have invested in research and development to develop the technology used by the standard. ${ }^{4}$

FRAND commitments have taken on increasing importance in recent years as courts have been called upon to decide what they mean, ${ }^{5}$ and as the Federal Trade Commission has brought antitrust actions to enforce those commitments. ${ }^{6}$ This litigation is largely a function of ambiguities and

3. A recent survey of SSO patent policies can be found in RUDI BEKKERS \& ANDREW Updegrove, A Study of IPR Policies AND Practices of A RePresentative Group of Standards SETTING ORganizations WorldWIDE (2012), http:/sites.national academies.org/PGA/step/IPManagement/PGA_072197, which is part of a project by the National Academies of Science. See Patent Challenges for Standard-Setting in the Global Economy: Lessons from Information and Communications Technology, NATIONAL ACADEMIES, http://nap.edu/catalog.php?record_id=18510 (last visited Nov. 3, 2013). Earlier surveys of SSO patent policies can be found in Mark A. Lemley, Intellectual Property Rights and StandardSetting Organizations, 90 CALIF. L. REV. 1889 (2002) [hereinafter Lemley, SSOs] and Benjamin Chiao, Josh Lerner \& Jean Tirole, The Rules of Standard-Setting Organizations: An Empirical Analysis, 38 RAND J. ECON. 905 (2007). For a recent survey of licensing disclosure policies, see Jorge Contreras, Technical Standards and Ex Ante Disclosure: Results and Analysis of an Empirical Study, 53 JURIMETRICS 163 (2013). We do not discuss in this paper SSOs that merely require disclosure of patents but do not require licensing of those patents. That was more common at the time of Lemley's 2002 paper, but disclosure-only policies have fallen into disfavor, in part because of abuse of those policies by companies like Rambus. See id. at 166 n.9, 180; Lemley, SSOs, supra.

4. See, e.g., U.S. DeP'T of Justice \& U.S. Patent \& Trademark OfFice, Policy Statement on REMEDiEs for Standards-Essential Patents SubJeCt TO Voluntary F/RAND COMMITMENTS 5 (2013), available at http://www.justice.gov/atr/public/ guidelines/290994.pdf.

5. See, e.g., Microsoft Corp. v. Motorola, Inc., 696 F.3d 872 (9th Cir. 2012); Broadcom Corp. v. Qualcomm, Inc., 501 F.3d 297 (3d Cir. 2007); Apple, Inc. v. Motorola Mobility, No. 11-CV-178-BBC, 2012 WL 5416941 (W.D. Wisc. Oct. 29, 2012); Apple, Inc. v. Samsung Elecs. Co., No. 11-CV-01846-LHK, 2012 WL 2571719 (N.D. Cal. June 30, 2012); Apple, Inc. v. Motorola Inc., No. 11-CV-08540, 2012 WL 1959560 (N.D. Ill. May 22, 2012); Microsoft Corp. v. Motorola, Inc., 864 F. Supp. 2d 1023 (W.D. Wash. 2012). For a table listing all FRAND litigation, see Jorge L. Contreras, Fixing FRAND: A Pseudo-Pool Approach to Standards-Based Patent Licensing, app. 1 (Mar. 13, 2013) (unpublished manuscript), http://works.bepress.com/jorge_contreras/6/.

6. See, e.g., Complaint, Motorola Mobility LLC, No. 121-0120 (F.T.C. Jan. 3, 2013), available at http://www.ftc.gov/os/caselist/1210120/130103googlemotorolacmpt.pdf; Statement of the Federal Trade Commission, Robert Bosch GmbH, No. 121-0081 (F.T.C. 2013), available at http://www.ftc.gov/os/caselist/1210081/121126boschcommission statement.pdf; Complaint, Negotiated Data Solutions LLC (N-Data), No. C-4234, 2008 WL 4407246 (F.T.C. Sept. 23, 2008); Dell Computers, Inc., 121 F.T.C. 616 (1996). 
omissions in the FRAND system used by most SSOs. The effectiveness of the FRAND commitment has been undermined by these ambiguities and omissions, especially for standards in the information technology sector.

In this Article, we propose best practices for SSOs in implementing the FRAND commitment. Under our proposal, owners of standard-essential patents agree to license their portfolio of standard-essential patents on FRAND terms, with the portfolio royalty rate determined through binding arbitration if necessary. SSOs adopting our proposal will more effectively achieve the twin goals of FRAND commitments noted, supra: freedom to implement the standard along with reasonable returns to inventors who contribute patented technology to the standard. Our approach is flexible: SSOs can adopt our basic structure with variations designed to fit their individual needs and circumstances. Indeed, patentees can choose to abide by the arbitration commitment even if the SSO does not compel it.

Substantively, our proposal is designed to steer bilateral, ex post negotiations towards royalty rates that reflect the outcome of ex ante technology competition. ${ }^{7}$ Our proposal achieves this (a) by protecting implementers from the threat that they will face an injunction or exclusion order, but (b) only for implementers who agree to pay a reasonable royalty rate, as determined through binding arbitration if necessary. Procedurally, our proposals are designed to be as simple, unambiguous, and transparent as possible.

The key to our approach is to bind patentees to engage in arbitration over the reasonable royalty with any willing licensee, rather than litigating the patents in court. We favor baseball-style arbitration, under which each party submits its final offer to the arbitrator, who then must pick one of those two offers. Under our proposal, a patentee who makes a FRAND commitment promises to forego court enforcement of its standard-essential patents in favor of arbitration over the royalty rate with any implementer of the standard willing to engage in such arbitration. ${ }^{8}$

If SSOs follow our proposal for resolving FRAND disputes, many of the issues that have occupied the courts will become moot, at least for future

7. We refer to negotiations that take place before the standard is adopted as ex ante negotiations. Negotiations that take place after the standard has been implemented are referred to as expost negotiations. Actual ex ante negotiations are often difficult or infeasible, in part because not all of the parties with an interest in deploying a standard belong to the SSO. Nothing in our proposal discourages or prevents negotiations at an early stage.

8. For other proposals to have a neutral fact-finder determine a FRAND royalty rate, see Kai-Uwe Kuhn, Fiona Scott Morton \& Howard Shelanski, Standard Setting Organizations Can Help Solve the Standard Essential Patents Licensing Problem, 3 COMPETITION POL'Y INT'L Antitrust CHRON. (SPECIAL Issue) 1, 4-5 (Mar. 2013). 
standards. Under a FRAND regime of the sort we propose, there is no need for the SSO to be substantively involved in deciding what is reasonable, no need to decide whether one party or another breached a contract so long as they participated in the arbitration, no need to decide whether a patent holder's offer was actually a FRAND offer, no need to worry about which jurisdiction is litigating the issue, and no need for antitrust law to intervene so long as the parties are abiding by their FRAND commitments.

We recognize that the vast majority of patent litigation does not involve standard-essential patents. ${ }^{9}$ SSO FRAND policies must be understood in the context of the broader operation of the patent system. Making FRAND commitments clear and enforceable may reduce the leverage of standardessential patent owners in negotiations with implementers who own patents that are not standard-essential. Our hope is that the U.S. Patent and Trademark Office will continue to improve patent quality and reduce patent pendency, and the courts will continue to make improvements in the general treatment of patent remedies, so that owners of FRAND-encumbered patents are not unfairly disadvantaged in comparison with owners of patents that are not standard-essential. We do not regard broader problems with the patent system as a reason to preserve a poorly functioning set of SSO patent rules.

In Part I, we address the issues that must be resolved to give effect to a FRAND commitment, and we propose a set of best practices for resolving those issues. ${ }^{10}$ In Part II, we consider a number of questions that frequently arise in standard-essential patent FRAND litigation that by and large become moot under our proposed FRAND regime.

\section{PROPOSED APPROACH TO FRAND COMMITMENTS}

We describe and explain here our proposed approach to FRAND commitments. SSO best practice begins with an explicit articulation in the SSO's intellectual property ("IP") rules of the twin goals of the FRAND regime: freedom to implement the standard along with reasonable returns to inventors who contribute patented technology to the standard. ${ }^{11}$ Those

9. Timothy Simcoe et al., Competing on Standards? Entrepreneurship, Intellectual Property, and Platform Technologies, 18 J. ECON. \& MANAGEMENT STRATEGY 775, 787 (identifying a total of 949 standard-essential patents litigated over a period of many years; for comparison, there were over 5000 patent suits filed in 2012 alone).

10. For an argument encouraging the adoption of best practices by SSOs, see Michael A. Lindsay, Safeguarding the Standard: Standards Organizations, Patent Hold-up, and Other Forms of Capture, 57 AnTiTRust Bull. 17, 30-31 (2012).

11. Looking at a large number of SSOs, Bekkers and Updegrove noted: 
reasonable returns reflect the ex ante value of the patented technology, not the additional ex post value resulting from the standardization itself. As one of us wrote fifteen years ago, "Reasonable should mean the royalties that the patent holder could obtain in open, up-front competition with other technologies, not the royalties that the patent holder can extract once other participants are effectively locked in to use technology covered by the patent." 12 As we discuss below, this interpretation of "reasonable royalties" comports with patent law and is now widely accepted by economists and policy makers.

\section{A. Basic Structure of THE FRAND REgIME}

Patent owners have the right to exclude others from practicing their technology (subject to the limits of equity, which will not always grant injunctions), ${ }^{13}$ or to trade that right for valuable consideration. SSO FRAND rules are designed to get parties to pre-commit to license their essential patents on reasonable and non-discriminatory terms, preventing later efforts to disrupt the technology or hold up users of the standard for supracompetitive royalties. ${ }^{14}$ Put another way, the FRAND commitment is at its base an agreement not to exercise the full scope of the patentee's rights in exchange for having its technology adopted as an industry standard, likely resulting in increased licensing opportunities.

For that commitment to be effective, it must be a legally binding obligation. A "FRAND commitment" that is nothing more than a promise to

$[\mathrm{N}]$ one of the policies attempts to even define what "fair" or "reasonable" fees are intended to mean in context. Nor do they state that at minimum, such fees must bear a reasonable relationship to the economic value of the IPR, despite the fact that this benchmark is stated explicitly by the FTC in its report on evolving [sic] IP marketplace, as well as in the European Commission's relevant Guidelines on horizontal cooperation agreements.

Bekkers \& Updegrove, supra note 3, at 102-03 (citations omitted).

12. Carl Shapiro \& Hal R. Varian, Information Rules: A Strategic Guide to THE NETWORK ECONOMY 241 (1999).

13. See eBay Inc. v. MercExchange LLC, 547 U.S. 388, 391-97 (2006).

14. On the holdup problem, see generally Mark A. Lemley \& Carl Shapiro, Patent Holdup and Royalty Stacking, 85 TEX. L. REV. 1991 (2007); Mark R. Patterson, Inventions, Industry Standards, and Intellectual Property, 17 BERKELEY TECH. L.J. 1043 (2002) [hereinafter Patterson, Inventions] (discussing the holdup inherent in ex post valuations of standardessential patents); Mark R. Patterson, Leveraging Information About Patents: Settlements, Portfolios, and Holdups, 50 Hous. L. REV. 483 (2012) [hereinafter Patterson, Leveraging Information About Patents]; Mark R. Patterson, Antitrust and the Costs of Standard-Setting: A Commentary on Teece \& Sherry, 87 MinN. L. REV. 1995, 2001 n.33 (2003) [hereinafter Patterson, Antitrust]; Joseph Scott Miller, Standard Setting, Patents, and Access Lock-in: RAND Licensing and the Theory of the Firm, 40 IND. L. REV. 351 (2007). 
later license to a party only if the patentee feels like it - the position some patentees have taken ${ }^{15}$ - is not a commitment at all. Rather, to work properly, the FRAND commitment must itself be an undertaking by the patentee to limit its rights, and SSOs should make it clear that they regard it as one. Our preferred approach is that the FRAND commitment be treated as an enforceable license agreement with reasonable terms to be determined in the future, though if SSOs impose the arbitration system we propose, that approach is not strictly necessary.

We propose that the FRAND commitment be defined as follows. An SSO participant who makes a FRAND commitment is obliged to make a "FRAND offer" to any interested party who agrees to reciprocate. A "FRAND offer" means a purely monetary offer to license the SSO participant's entire portfolio of standard-essential patents on reasonable and non-discriminatory terms for the purpose of making, using, or selling products that comply with the standard. Crucially, the SSO participant promises that, if it cannot come to terms with another party implementing the standard, the question of the proper FRAND royalty rate will be subject to binding, baseball-style (or "final offer") arbitration. ${ }^{16}$ SSO best practices include specifying a reputable arbitration association with established, unbiased rules for the conduct of the proceeding. The patentee's agreement to binding arbitration precludes it from going to court to enforce its standard-essential patents against implementers of the standard, except in very limited circumstances that we detail infra.

The obligation to make a FRAND offer does not prevent the standardessential patent owner from entering into an alternative licensing arrangement, such as a portfolio cross license, with an implementer of the standard. It will often make sense for private parties to enter into a deal that reflects their specific circumstances. To help facilitate these deals while giving effect to the non-discrimination prong of FRAND, SSO best practices should include a mechanism by which the owner of standard-essential patents is obligated to disclose to any willing licensee the terms on which it has already licensed its standard-essential patents to other parties, subject to a suitable mechanism to protect the owner's confidential non-price business information.

The FRAND commitment in no way prevents or discourages private licensing agreements, and indeed we think they will be the norm. ${ }^{17}$ Rather,

15. See, e.g., Broadcom Corp. v. Qualcomm, Inc., 501 F.3d 297, 313-14 (3d Cir. 2007).

16. See infra Section I.B.2.

17. One complication comes from the "non-discriminatory" prong of the FRAND commitment. A patent owner making a FRAND commitment is obliged to offer similar 
the FRAND commitment provides a fallback position (what economists call a threat point) should those negotiations fail. All of the nuances discussed infra come into play only if the owner of a patent subject to a FRAND commitment and an implementer are unable to reach an agreement giving the implementer the patent licensing rights necessary to produce products that comply with the standard. And no government actor is compelling this fallback position; it is a voluntary commitment between patent owners and the SSO, for the benefit of future implementers of the standard. ${ }^{18}$

\section{B. What Happens When Negotiations Fail?}

Under our proposal, if a standard-essential patent owner and an implementer of the standard cannot agree on license terms, the patent owner is obligated to enter into binding arbitration to determine the FRAND royalty rate for its entire portfolio of standard-essential patents, so long as the implementer makes a reciprocal FRAND commitment for patents reading on the standard in question. ${ }^{19}$ We denote an implementer who agrees to reciprocity and binding arbitration as a "willing licensee." If a standardessential patent owner offers to enter into binding arbitration and the implementer refuses to make a reciprocal commitment or to submit to arbitration, the patent owner's FRAND commitment not to go to court to enforce its standard-essential patents against that party has been discharged.

\section{Injunctions}

As a best practice, SSOs should explicitly state in their IP policies that a patent holder making a FRAND commitment has given up its right to seek

terms to similarly situated parties. However, that does not mean that everyone must always pay the same price. Different types of buyers may reasonably be treated differently, and buyers who bring their own value to the table in the form of other patents to trade should generally expect to pay less than those who do not. For discussion of cross licenses and their implicit valuation of patents, see Mark A. Lemley \& A. Douglas Melamed, Missing the Forest for the Trolls, 113 Colum. L. REV. (forthcoming 2013), available at http://ssrn.com/abstract=2269087.

18. For this reason, whatever concerns have been expressed over Federal Trade Commission ("FTC") enforcement actions about the First Amendment right to petition the courts do not apply here. See, e.g., Statement of Commissioner Maureen K. Ohlhausen, Statement of the Federal Trade Commission, Robert Bosch GmbH, No. 121-0081 (F.T.C. 2013), available at http://www.ftc.gov/os/caselist/1210081/121126boschohlhausen statement.pdf (articulating the First Amendment argument). An arbitration agreement is not state action limiting a patentee's right to sue, only a private agreement that does not raise constitutional issues.

19. While we want to encourage negotiation, patents have a limited life, and "willing" licensees should not be able to drag unproductive negotiations out forever. We suggest that either party can give the other a sixty-day notice of intent to seek binding arbitration; failing to participate in the arbitration triggers the remedies we discuss, infra. 
an injunction against any willing licensee for infringement of any of its standard-essential patents. The commitment to binding arbitration aligns well with that approach. The matter of the FRAND royalty rate will be litigated in front of a private decision maker who does not have the power to issue an injunction. The FRAND commitment is also not consistent with seeking an exclusion order at the International Trade Commission ("ITC"), which is an injunction by another name. Making binding arbitration the exclusive remedy will preclude resort to the ITC in an effort to end-run the FRAND commitment, something scholars, the PTO, and antitrust agencies have urged in recent years. ${ }^{20}$

Explicitly ruling out injunctions will tend to steer bilateral negotiations towards a reasonable royalty rate. A key principle of bargaining theory is that the threat points of the two parties, along with their bargaining skills (which determine how their combined gains from reaching a deal are split), govern the outcome of bilateral negotiations. ${ }^{21}$ So long as the arbitration procedure itself is unbiased, bargaining in the shadow of binding arbitration will tend to lead to reasonable rates. Introducing injunctions would drive negotiated royalty rates away from reasonable rates to artificially high ones reflecting the threat of holdup. ${ }^{22}$

20. U.S. Dep’t of Justice \& U.S. Patent \& Trademark Office, Policy STATEMENT ON REMEDies FOR STANDARDS-ESSENTIAL PATENTS SubjeCt TO VOLUNTARY F/RAND Commitments, supra note 4; Federal Trade Commission, Third Party United States Federal Trade Commission's Statement on the Public Interest, Certain Gaming and Entertainment Consoles, Related Software, and Components Thereof, Inv. No. 337-TA-752 (USITC 2013), available at http://www.ftc.gov/os/2012/06/1206ftcgamingconsole.pdf; see also Colleen V. Chien \& Mark A. Lemley, Patent Holdup, the ITC, and the Public Interest, 98 CORNELL L. REv. 1, $2-5$ (2012). Notably, in a recent ITC investigation instigated by InterDigital Communications, the Commission refused to allow the investigation to go forward where the dispute arose under a license agreement that provided for arbitration. Notice, Certain Wireless Devices with $3 \mathrm{G}$ Capabilities \& Components Thereof, Inv. No. 337-TA-800, 2013 WL 3361874 (USITC June 28, 2012). The fact that the ITC will enforce an arbitration agreement unless the claim of arbitrability is "wholly groundless," Qualcomm Inc. v. Nokia Corp., 466 F.3d 1366, 1371, 1373 n.5 (Fed. Cir. 2006), while courts must stay resolution of a patent lawsuit pending an ITC proceeding, is an important benefit of the arbitration approach over judicial resolution.

21. See Lemley \& Shapiro, supra note 14 , at 1995-98 (providing an example of a bargaining model).

22. Chien \& Lemley, supra note 20, at 8; Joseph Farrell et al., Standard Setting, Patents, and Hold-Up, 74 Antitrust L.J. 603, 616 (2007); Lemley \& Shapiro, supra note 14; Doug Lichtman, Understanding the RAND Commitment, 47 Hous. L. REV. 1023, 1033 (2010); Carl Shapiro, Injunctions, Hold-Up, and Patent Royalties, 12 Am. LAW \& ECON. REv. 280 (2010). Ratliff and Rubinfeld find otherwise, but that's because they assume in their model that an injunction will only be granted after a FRAND rate has been finally set by a court and an implementer refuses to pay it. James Ratliff \& Daniel L. Rubinfeld, The Use and Threat of Injunctions in the RAND Context, 9 J. COMPETITION L. \& ECON. 1, 13, 21-22. That's not the 
The standard-essential patent owner may seek an injunction against an unwilling licensee, as we discuss, infra. However, the court may well not grant an injunction. The court may well conclude that an SSO participant who has made a FRAND commitment has already declared that royalties are sufficient to compensate it for infringement by compliant products, so that the SSO participant will suffer no irreparable harm from infringement of its standard-essential patents. ${ }^{23}$

\section{Procedure}

We suggest that SSOs specify that disputes over what is FRAND be resolved through binding arbitration, "baseball-style." 24 In baseball-style arbitration, the parties produce evidence and argument before the arbitrator, and then they each propose a royalty number. The arbitrator must pick one of the two numbers offered and cannot come up with her own number. Using baseball-style arbitration logically drives the parties towards making reasonable proposals, because the party that asks for too much (or offers too little) risks losing the case altogether. ${ }^{25}$ FRAND disputes are well suited to baseball-style arbitration, because the only thing at issue is which of two numbers in fact represents the more reasonable royalty. ${ }^{26} \mathrm{We}$ provide more details on how to determine that royalty in Section I.B.3, infra.

way things have happened in the real world. Patentees have sought injunctions in German courts and in the ITC without any resolution of FRAND issues. See Order, Interdigital Commc'ns Inc. v. Huawei Techs. Co., No. 1:13-cv-00008-RGA (D. Del. Mar. 14, 2013) (refusing to stay ITC proceeding that might lead to an injunction pending resolution of a FRAND royalty rate to which all defendants had agreed to be bound).

23. See, e.g., Apple, Inc. v. Motorola, Inc., 869 F. Supp. 2d 901 (N.D. Ill. 2012) (Posner, J., sitting by designation). There may be policy reasons to prefer granting injunctions against unwilling licensees to encourage implementers to use the arbitration system we propose. In prior work, we have argued that injunctions should be available against defendants who copy a technology and seek to game the patent system by refusing to pay a reasonable royalty. Lemley \& Shapiro, supra note 14, at 2036. Some, though not all, unwilling licensees will fit into this category.

24. Some SSOs already require arbitration of disputes. See, e.g., VMEBUS INT'L TRADE ASS’N, VSO POLICIES AND PROCEDURES \ 10.5 (2009), http:/ /www.vita.com/home/VSO/ vso-pp-r2d6.pdf; Digital Video Broadcasting, MEMORANDum of Understanding $\int 14.7$ (2011), http://www.dvb.org/documents/DVB-MoU-2011.pdf.

25. J. Gregory Sidak, Court-Appointed Neutral Economic Experts 31 J. Competition L \& Econ., Working Paper, Apr. 21, 2013) ("[Baseball-style] arbitration has the effect of generating more credible estimates by altering the incentives of experts for either side to generate extreme values for their clients.").

26. One complication is that royalties in the real world are sometimes structured as lump-sum payments and sometimes as a percentage of ongoing sales. One of us has argued elsewhere that running royalties are better when calculating ongoing rather than past commitments. Mark A. Lemley, The Ongoing Confusion over Ongoing Royalties, 76 MO. L. REV. 695 (2011). But if both parties phrase their proposals in the same units, it doesn't matter 
Baseball-style arbitration has a number of other advantages. The arbitrator does not need to decide whether any given patent is valid and infringed. Nor does she need to decide whether a particular patent is essential except in unusual circumstances. ${ }^{27}$ Both of those things may be contested, and the evidence on each question will likely influence the reasonableness of the competing royalty proposals. But unlike a court that might have to rule on any number of subsidiary factual issues, the only thing the arbitrator needs to do is pick the better of two proposed royalty rates.

Under SSO best practices, any arbitration decision will be disclosed to willing licensees. ${ }^{28}$ This disclosure is justified by the non-discrimination provision; it is hard to know whether a royalty unfairly favors one party unless we also know what other parties had to pay. Disclosure to willing licensees has other advantages: it will encourage implementers to submit to arbitration, reduce the need for duplicative arbitrations, avoid giving one party an informational advantage if they have already been involved in an arbitration, and help build a record of what constitutes FRAND royalty rates that may encourage subsequent parties to resolve their disputes themselves. In any given arbitration, the standard-essential patent owner and the licensee may well prefer to keep the arbitration outcome secret. For the reasons just given, such secrecy would undermine the effectiveness of the FRAND regime. And in any event, courts are not likely to permit it, at least when a

which they choose. If one party argues for a lump sum and the other for a running royalty, the arbitrator is choosing between apples and oranges. That makes the arbitrator's job harder, but by no means impossible; she simply must decide which approach better reflects what hypothetical negotiators would have chosen in that particular instance. If necessary, she can specify the royalty structure (e.g., lump sum vs. running royalties, or the royalty base to be used) to facilitate an apples-to-apples comparison of the rates proposed by the two parties. Beyond this, we do not think the arbitrator needs to or should resolve disputes over other non-price license terms. A FRAND license is by definition neither temporally limited nor limited to producing a set number of products; it provides terms that apply whenever the licensee makes products implementing the standard during the term of the patents. So there is no need for an arbitrator to decide on non-price terms like duration or output limits; there are no such terms. We can imagine parties wanting to include other limits in a license, and of course they are free to do so if they agree. But the FRAND obligation doesn't compel any such terms, so the arbitrator should not have to resolve them.

27. We can imagine a situation in which the parties to an arbitration dispute whether a particular patent is within the definition of an "essential" patent, and therefore whether the award will include a license to that patent. In that circumstance, it would be best if the arbitrator specified whether the patent in question is "essential" to minimize future litigation over whether or not certain patents have been licensed under the arbitration award.

28. Willing licensees also should have access to the terms on which these same standard-essential patents have been licensed to others, subject to suitable protections of confidential business information. 
party to a subsequent dispute can show that the information is potentially relevant. $^{29}$

Finally, like any arbitration, opportunities for appeal will be limited under this approach. Generally, parties to an arbitration can appeal only in cases of legal error or some procedural deficiency. ${ }^{30}$

\section{Reasonable Royalties}

The concept of a "reasonable royalty" is the heart of the patentee's right under the FRAND commitment, and it is the one thing the arbitrator will be called upon to decide. SSOs may differ in how they prefer to implement the FRAND concept. In an ideal world, SSOs would offer detailed guidance on what constitutes a reasonable royalty for a portfolio of standard-essential patents, whether or not they adopt all of the principles we favor. But they rarely do so. ${ }^{31}$ In the absence of particularized guidance from an SSO, we offer a set of principles regarding the "reasonable royalty" concept that we believe should have widespread support.

Our starting point is the concept of reasonable royalties from U.S. patent law. The courts are very familiar with this concept, which they calculate in most patent damages cases. ${ }^{32}$ That is not to say they always do it perfectly; far

29. See, e.g., In re MSTG, Inc., 675 F.3d 1337, 1348 (Fed. Cir. 2012).

30. Hall St. Assocs. LLC v. Mattel, Inc., 552 U.S. 576 (2008) (enumerating limited grounds for appeal of arbitration award). There is some risk that if the patentee gets to choose the arbitration service, it will choose one known to be biased in its favor. But while courts are generally deferential to arbitral decisions, they have proven willing to intervene to reject arbitration agreements that are procedurally unfair. See, e.g., Wheeler v. Noteworld LLC, No. 11-35984, 506 F. App'x. 543 (9th Cir. 2013) (affirming conclusion that abusive provisions in arbitration agreement were unconscionable).

31. See Lemley, SSOs, supra note 3 at 1913-14.

32. For an extended discussion of the relationship between damages under patent law and the FRAND concept in an SSO context, see Suzanne Michel, Bargaining for RAND Royalties in the Shadow of Patent Remedies Law, 77 ANTITRUST L.J. 889 (2011). 
from it. ${ }^{33}$ But we focus here on issues specific to the FRAND regime, not the more general challenge of determining reasonable royalty rates. ${ }^{34}$

Under patent law, a reasonable royalty normally is based on a hypothetical, arms-length negotiation between a willing buyer and a willing seller that takes place at the time the infringement begins. ${ }^{35}$ For standardessential patents, a reasonable royalty should be based on a hypothetical, arms-length negotiation that takes place at the time the SSO is setting the standard. ${ }^{36}$ For parties making a FRAND commitment during the standardsetting process, the reasonable price is the price they would negotiate at that point, not a price that differs for each implementer depending on the happenstance of when that party begins implementing the standard. SSO

33. For criticism of particular reasonable royalty doctrines and suggestions for improvement, see, for example, Daralyn J. Durie \& Mark A. Lemley, A Structured Approach to Calculating Reasonable Royalties, 14 LEWIS \& ClarK L. REV. 627 (2010); Amy L. Landers, Patent Claim Apportionment, Patentee Injury, and Sequential Innovation, 19 GEO. MASON L. REV. 471 (2012); Amy L. Landers, Let the Games Begin: Incentives to Innovation in the New Economy of Intellectual Property Law, 46 SANTA ClARA L. REV. 307 (2006) [hereinafter Landers, Let the Games Begin]; Mark A. Lemley, Distinguishing Lost Profits from Reasonable Royalties, 51 WM. \& MARY L. ReV. 655 (2009); Brian J. Love, The Misuse of Reasonable Royalty Damages as a Patent Infringement Deterrent, 74 Mo. L. REV. 909 (2009); Brian J. Love, Patentee Overcompensation and the Entire Market Value Rule, 60 STAN. L. REV. 263, 278 (2007) [hereinafter Love, Patentee Overcompensation].

34. For example, issues of royalty base, double payment, and upstream/downstream rights have come up in ordinary patent cases as patentees have moved from targeting makers of components to going after downstream customers and even individual end users. See, e.g., Tim Steller, Local Firm Faces Heat of Patent Enforcer, ARIZ. DAILY STAR, Feb. 17, 2013, http:/ / azstarnet.com/news/local/tim-steller-local-firm-faces-heat-of-patent-enforcer/

article_456aaa3f-893e-5465-8e93-73c849415fad.html (describing a growing trend of large companies sending demand letters to small businesses stating that they own patents to "common technologies or processes"). Those issues, thorny as they are, are not unique to the FRAND context. See, e.g., Quanta Comp. v. LG Elecs., 553 U.S. 617 (2008) (discussing the rules of patent exhaustion when patentees seek to recover from both upstream and downstream companies).

35. See Lemley, supra note 33, at 666-68.

36. As noted, supra, the idea that a reasonable royalty should reflect the ex ante value of the patented technology, over and above the best alternative, is far from new. This is the approach recommended by the Federal Trade Commission. See FED. Trade Comm'N, THE Evolving IP MARKetPlace: Aligning Patent Notice AND REMEdies With COMPETITION 22-23 (2011), available at http://www.ftc.gov/os/2011/03/110307patent report.pdf. The European Commission also takes this approach. European Comm'n, Guidelines on the Applicability of Article 101 of the Treaty on the Functioning of the European Union to Horizontal Co-operation Agreements, 2011 O.J. (C 11) 1 289, available at http:/ / eur-lex.europa.eu/LexUriServ/LexUriServ.do?uri=OJ:C:2011:011:0001:0072:EN:PDF. This basic idea is discussed in Farrell, et al., supra note 22, and is reflected in the ex ante auction model advocated by Dan Swanson and William Baumol. Daniel G. Swanson \& William J. Baumol, Reasonable and Nondiscriminatory (RAND) Royalties, Standard Selection, and the Control of Market Power, 73 ANTITRUST L.J. 15 (2005). 
best practice includes explicitly noting the timing and context for the hypothetical ex ante negotiation underlying the reasonable royalties concept.

The hypothetical negotiation needs to take place under conditions where the alternative specifications have been identified, so that the parties are well informed about the best potential non-infringing alternatives to the proposed standard. ${ }^{37}$ In some cases, the best ex ante technological alternatives would have required some development effort by SSO participants, and could not simply have been taken off the shelf. The key idea here is that a reasonable royalty should reflect what would happen as a result of well-informed ex ante technology competition. The incremental value of the patented technology over and above the next-best alternative serves as an upper bound to the reasonable royalties. To this end, SSO best practice includes maintaining records, such as minutes from SSO meetings, that will inform subsequent negotiators and arbitrators of the ex ante technical alternatives that were feasible or considered, along with their pros and cons.

By construction, the reasonable royalty rate does not include the value attaching to the creation and adoption of the standard itself. ${ }^{38}$ To allow patentees to capture that value, which flows from the collective adoption decisions of the group rather than from the underlying value of the technology chosen, would undermine the goals of the FRAND commitment. $^{39}$

37. The hypothetical ex ante negotiation is not intended to reflect what an actual ex ante negotiation would have looked like. For starters, SSO participants were unlikely to have known what patents covered what specifications. But reasonable royalty calculations have always assumed a counterfactual world. The point is not to reconstruct what the parties actually did; obviously they did not agree on a price ex ante, or there would be no dispute. Rather, the point of the hypothetical negotiation rule in patent damages is to determine what hypothetical reasonable parties might have done, had they had all the facts, including knowledge of non-infringing alternatives. See, e.g., Grain Processing Corp. v. Am. MaizeProds. Co., 185 F.3d 1341, 1350-53 (Fed. Cir. 1999). The FRAND royalty concept is no different in this respect.

38. Apple, Inc. v. Motorola, Inc., 869 F. Supp. 2d 901, 913 (N.D. Ill. 2012); Patterson, Inventions, supra note 14, at 1048; Mark A. Lemley, Ten Things to Do About Patent Holdup of Standards (and One Not to), 48 B.C. L. REV. 149, at 158-59 (2007).

39. For this reason, the hypothetical bilateral negotiation can, if necessary, involve some communication, but not explicit coordination, among SSO members who are implementers to avoid an outcome in which the patent holder uses a "divide and conquer" strategy to support royalty terms and an associated equilibrium technology adoption outcome that is inferior to another equilibrium for a blocking coalition of implementers. See generally Ilya Segal \& Michael D. Whinston, Robust Predictions for Bilateral Contracting with Externalities, 71 ECONOMETRICA 757 (2003) (studying bilateral contracting between one principal and some number of agents where each agent's utility depends on the principal's unobservable trades with other agents). For an analysis of how independent, bilateral negotiations, along with the non-discrimination prong of FRAND, can deter patent holdup, 
The hypothetical negotiation over the FRAND commitment is a bilateral negotiation between the patent holder and one implementer. That doesn't mean other implementers are irrelevant. Deals with those parties may be evidence of a reasonable price, and certainly constitute relevant evidence in the arbitration. Plus, deals with other parties may be binding due to the nondiscrimination commitment. ${ }^{40}$ But the hypothetical ex ante negotiation is not one in which all the buyers act collectively to reduce prices. ${ }^{41} \mathrm{It}$ is one in which patentees negotiate with individual licensees just as they would in any other circumstance, subject to the constraint that they have pre-committed not to discriminate. ${ }^{42}$ The commitment to license to all comers makes the auction approach proposed by some $e^{43}$ inappropriate.

Royalty stacking arises when implementers must pay royalties to multiple patent owners, so those royalties cumulate or "stack" on top of each other from the perspective of the implementer. ${ }^{44}$ To address the problem of royalty stacking, the hypothetical negotiation needs to reflect the presence of patents held by others that read on the same product. A real-world negotiation would not consider in a vacuum one party's standard-essential patent portfolio, or even the standard-essential patents associated with one of many standards being implemented in a given product. The price any implementer would be willing to pay for a given standard-essential patent portfolio depends on the other royalty payments they will be asked to make to bring their product to market. For that reason, the hypothetical negotiation needs to reflect and account for reasonable royalties for standard-essential patents held by others,

see Richard Gilbert, Deal or No Deal? Licensing Negotiations in Standard-Setting Organizations, 77 ANTITRUST L.J. 855 (2011).

40. We do not discuss the non-discrimination commitment in detail here. For other work considering it, see, for example, Lemley, supra note 3, at 1913-14; Intellectual Property and Standard-Setting, in ABA HANDBOOK ON THE ANTITRUST ASPECTS OF STANDARDS SETTING 95 (2d ed. 2011); Gilbert, supra note 39.

41. On the risk of buyers' cartel inherent in SSO IP policies, see 2 HERBERT HovenkAmP ET AL., IP AND ANTITRUST \36.6b (2010); see also Carl Shapiro, Setting Compatibility Standards: Cooperation or Collusion?, in EXPANDING THE BOUNDS OF INTELLECTUAL PROPERTY 81 (2001).

42. For example, a patentee who makes or sells compliant products cannot charge a higher royalty to an implementer against whom the patentee competes directly than to another party who sells very distinct compliant products.

43. See, e.g., Damien Geradin, Anne Layne-Farrar \& A. Jorge Padilla, The Ex Ante Auction Model for the Control of Market Power in Standard Setting Organizations (Apr. 9, 2007) (unpublished manuscript), http://ssrn.com/abstract=979393; David L. Newman, Going Once ... Going Twice ... Licensed Under the Most Reasonable and Non-Discriminatory Bidding Terms!, 11 Nw. J. TECH. \& INTELl. PROP. 139 (2013). An auction presupposes licenses to a subset of bidders, instead of all of them, as FRAND requires.

44. See, e.g., Lemley \& Shapiro, supra note 14, at 1993. 
just as a reasonable royalty in patent damages, properly understood, must include the concept of apportionment of the value of a product among multiple contributors to that value. ${ }^{45}$ This is part of what is intended by the "well-informed" aspect of the hypothetical ex ante negotiations.

SSO best practices should include an instruction to the arbitrator to consider all patents declared essential to the standard in question, not just the portfolio of standard-essential patents submitted to arbitration. The economics literature demonstrates that when multiple essential inputs are priced independently, collective overpricing tends to result, due to the "Cournot complements" problem. ${ }^{46}$ This overpricing, which appears in practice in the form of royalty stacking, reduces the collective returns to standard-essential patent owners and to implementers. ${ }^{47}$ To avoid this mutually undesirable outcome, SSO best practices should acknowledge the problem of royalty stacking, empower the arbitrator to account for royalty stacking, and provide the arbitrator with the best possible information to do so. ${ }^{48}$ Arbitrators (and courts) can gain insight from the commercial arrangements companies have employed to deal with royalty stacking, notably in the context of patent pools or other mechanisms involving the aggregation of essential patents. ${ }^{49}$ An arbitrator does not have the luxury of resolving all standard-essential patent disputes together, at least absent some

45. See, e.g., Landers, Let the Games Begin, supra note 33, at 354-62; Love, Patentee Overcompensation, supra note 33, at 268-69; Patterson, Leveraging Information About Patents, supra note 14 , at $503-13$.

46. The "Cournot complements" problem arises when multiple necessary inputs are supplied by separate firms, each with market power. In Cournot's original example, one firm had a monopoly over copper and another had a monopoly over zinc, two inputs essential for making brass. ANTOINE Augustin COURnOt, RESEARCHES INTO THE MATHEMATICAL Principles OF THE THEORY OF WeAlth 99-116 (Nathaniel T. Bacon trans., Augustus M. Kelley Publishers 1971) (1838). For discussion in the context of patents, see Lemley \& Shapiro, supra note 14, at 2013-17; Carl Shapiro, Navigating the Patent Thicket: Cross Licenses, Patent Pools, and Standard Setting, 1 InNOVATION POLICY \& ECON. 119, 122-24 (2000).

47. A lower aggregate royalty rate would lead to more sales of the final product, raising the profits of the patent holders and the implementers. See Shapiro, supra note 14, at 2013-17.

48. Royalty stacking applies to all of the patents reading on a given product, not just the standard-essential patents associated with the standard at issue. Therefore, in principle, the reasonable aggregate royalty rate for all standard-essential patents reading on a given standard should depend on the entire set of patents reading on the product. SSOs may want to point this out, as part of providing guidance to the arbitrator. However, it may be difficult in practice for the arbitrator to learn about and account for patents other than standardessential patents associated with the standard at issue. The arbitrator may find it more workable to maintain a focus on the ex ante incremental value of the standard-essential patents at issue.

49. See Shapiro, supra note 46, at 134-36; Richard J. Gilbert, Antitrust for Patent Pools: A Century of Policy Evolution, 2004 STAN. TECH. L. REV. 3, ๆ 2. 
mechanism in the SSO rules to handle all standard-essential patent disputes on the same patent in the same arbitration proceeding. ${ }^{50}$ But the arbitrator can and should take evidence on the existence of other standard-essential patent portfolios the licensee would have to pay; that evidence bears on the royalty rate. $^{51}$

We close this Section by noting two significant respects in which a FRAND royalty arbitration is different than a patent damages case. First, in a FRAND royalty arbitration, there is no need to determine the reasonable royalty on a patent-by-patent basis. Indeed, doing so would be exceedingly difficult and costly for large patent portfolios. The FRAND concept involves a reasonable rate for a party's entire portfolio of standard-essential patents. ${ }^{52}$ Establishing a FRAND rate for an entire standard-essential patent portfolio is simpler than - and matches more closely to-real-world licensing practices in the information technology sector, where implementers commonly negotiate portfolio licenses that give them freedom to operate. ${ }^{53}$

Second, unlike the "reasonable royalty" concept used to calculate damages in patent infringement cases, the hypothetical negotiation for FRAND purposes does not assume that any particular patent, much less the entire standard-essential patent portfolio, is valid and infringed. ${ }^{54}$ Unlike a patent infringement case, the reasonable royalty for a portfolio is a function of the probability that the patents in that portfolio are actually valid and infringed. ${ }^{55}$ Reasonable royalties will logically be lower for patents that are more likely to be found invalid or not infringed. That certainly does not

50. Some have suggested such a "pseudo-pool." See Contreras, supra note 5, at 26-33.

51. Evidence on pricing from patent pools may be relevant to pricing decisions in any event. See Jorge L. Contreras, Rethinking RAND: SDO-Based Approaches to Patent Licensing Commitments 14-15 (Oct. 10, 2012), http://ssrn.com/abstract=2159749.

52. There are some advantages to establishing a FRAND rate for a portfolio of standard-essential patents equal to the sum of the reasonable royalty rates for all of the individual standard-essential patents in that portfolio. Under this "neutrality principle," patent holders have no incentive to split up their portfolios, or combine them, to increase the overall FRAND royalty rate. However, the neutrality principle does not generally follow from the hypothetical, ex ante negotiation construct. Nor does it mean in practice that one needs to compute the FRAND rate for each patent.

53. See, e.g., Gideon Parchomovsky \& R. Polk Wagner, Patent Portfolios, 154 U. PA. L. REV. 1 (2005); Lemley \& Melamed, supra note 17.

54. For this reason, we cannot simply apply the reasonable royalty standards used in patent law, as some have suggested. See Anne Layne-Farrar, A. Jorge Padilla \& Richard Schmalensee, Pricing Patents for Licensing in Standard-Setting Organizations: Making Sense of FRAND Commitments, 74 ANTITRUST L.J. 671, 679-82 (2007).

55. A patent is inherently a probabilistic right. See Mark A. Lemley \& Carl Shapiro, Probabilistic Patents, 19 J. ECON. PERSP. 75 (2005) (discussing the economics of probabilistic patents). 
mean that the parties are required to litigate validity and infringement on a patent-by-patent basis, and we very much doubt they will want to do that for the entire portfolio. But the significance and strength of the portfolio is key to determining a reasonable price for that portfolio.

When arbitration is invoked, we expect that both parties will often present evidence on validity because it may affect the royalty awarded. ${ }^{56}$ This is entirely appropriate and desirable, just as parties negotiating a patent license typically spar over validity and infringement. The arbitrator should account for the likelihood of validity and infringement, along with the significance, of the patents at issue in deciding which of the two royalty rates proposed by the parties for a portfolio of standard-essential patents is more reasonable.

We don't mean to suggest that determining the FRAND royalty for a portfolio of standard-essential patents is an easy matter. It isn't. Indeed, we expect FRAND arbitration will often involve extensive discovery, given the range of information relevant to determining which of the two offers made is more reasonable. Nonetheless, the principles articulated here will make arbitration far more predictable than litigation, greatly increasing the efficiency and accuracy with which FRAND disputes are resolved.

\section{THE BOUNDARIES OF THE FRAND ARBITRATION}

There are some complications to the basic framework, though fewer than one might expect. Most center on determining the circumstances under which patent owners are able to enforce their standard-essential patents by means other than submitting them to binding arbitration for the determination of a FRAND royalty rate.

\section{Unwilling Patentees and Unwilling Licensees}

What happens if a standard-essential patent owner who has made a FRAND commitment with binding arbitration goes to court to enforce its standard-essential patents? The defendant in that proceeding would have the opportunity to argue that the patents asserted are essential to the standard and that the court should therefore compel arbitration, per the patentee's commitment. Motions to compel arbitration are routinely granted in the United States. ${ }^{57}$ And they are considered at the outset of a case. ${ }^{58}$ So a patentee cannot simply opt out of a binding arbitral commitment.

56. If both parties stipulate that a given patent is essential, infringement of that patent may not be disputed.

57. The Federal Arbitration Act, 9 U.S.C. $\iint 1-16$ (2012), declares a federal policy in favor of arbitration, Nitro-Lift Techs. v. Howard, 133 S. Ct. 500 (2012), and courts have 
Implementers, by contrast, have made no such commitment. When a patentee makes an arbitration demand to a potential licensee, the licensee can either choose to participate in the process or refuse to do so. If the implementer participates in the process, it will be bound by the result. It can't later decide it dislikes the result and refuse to pay. An arbitral award can be enforced in court. In addition, under our approach, if the patent holder can convince an authorized fact finder that the implementer is likely to evade paying the royalties or be unable to do so, the fact finder may require the implementer to make payments into escrow or post a suitable bond. If the implementer then fails to comply with this requirement, they are effectively refusing to participate in the process.

If the potential licensee refuses to participate in a royalty-setting arbitration as to a standard-essential patent, the patentee can sue that party in court for infringing that patent, seeking damages and injunctive relief. A commitment to license on reasonable terms is not a commitment to be whipsawed by a potential licensee. An implementer who agrees to participate only if it gets a result it likes ${ }^{59}$ is no different than a patentee who agrees to license on reasonable terms only if it gets to decide what is reasonable. Neither party is acting in good faith. A patentee who makes a FRAND commitment is obligated to agree to reasonable licensing terms, but does not have to license to someone who will not make a similar commitment to accept reasonable terms set by the arbitrator.

\section{Essential Versus Non-Essential Patents}

The FRAND commitment applies to standard-essential patents. Under our proposal, a patentee who makes a FRAND commitment is free to litigate normally over other, non-essential patents in its portfolio. But what happens when the parties cannot agree whether a patent is essential?

For starters, SSOs can and should limit disputes over what is an "essential" patent by clearly defining that term. Based on our experience, we suggest that the SSOs define a patent to be essential if any product complying with the standard will infringe on that patent. Any narrower

proven willing to enforce that policy even in controversial circumstances. See, e.g., AT\&T Mobility LLC v. Concepcion, 131 S. Ct. 1740 (2011) (enforcing clause banning class actions in favor of arbitration).

58. Indeed, normally any court proceedings must be stayed in favor of arbitration. See, e.g., In re Pharmacy Benefit Managers Antitrust Litig., 700 F.3d 109, 116 (2d Cir. 2012) (“a party to a valid and enforceable arbitration agreement is entitled to a stay of federal court proceedings pending arbitration as well as an order compelling such arbitration.").

59. See, e.g., Apple, Inc. v. Motorola Mobility, No. 11-CV-178-BBC, 2012 WL 5416941 (W.D. Wisc. Oct. 29, 2012). 
definition would not prevent patentees from holding up implementers. However, some SSOs may conclude that a broader definition, capturing some notion of "commercially essential" rather than just "technically essential," is superior for them.

One possible issue is over-declaring: patentees claiming patents are essential when they aren't. As a general matter, we don't see much risk in over-declaring given our approach. If a patentee declares patents essential, it commits itself to the arbitration procedure we have outlined. If the patent is not in fact truly essential, the patentee could have sued to enforce the patent in court and sought an injunction. The fact that the patentee voluntarily gives up those rights when it didn't need to doesn't create a problem for the rest of the world. We can imagine a patentee wanting to do this to pad its portfolio if the default or starting FRAND rate on a portfolio is proportional to the number of declared essential patents, but that can easily be solved by giving the other side the ability to argue that a particular patent isn't worth much because it is easy to design around (so it isn't essential). The arbitrator could determine whether a patent is truly essential, but we doubt she would have to in very many cases.

Another issue is under-declaring: trying to avoid a FRAND commitment on patents that truly are essential. This presents a more serious risk; a patent holder may seek to narrow, avoid, or evade its FRAND commitment by claiming that a given patent is not essential. ${ }^{60} \mathrm{~A}$ patentee that claims its patent is not essential presumably will not invoke the arbitration proceeding, but will instead sue in court or threaten litigation. If the SSO has made arbitration mandatory for essential patents, as we propose, a defendant in that lawsuit would have the opportunity to argue that the patent was in fact essential to the standard and therefore to compel arbitration. The court would have to determine whether the patent was in fact essential because it was technically necessary to comply with the standard. Similarly, if a patentee asserts a patent in court after binding arbitration is over and claims that the patent was not essential and therefore not part of the arbitration, the defendant could argue that the patent was essential and thus covered by the license.

We don't see a good alternative to courts making these determinations. We will note, however, that the behavior of the parties themselves will sometimes offer evidence on this score. A patentee asserting that

60. Some SSOs require a listing of essential patents, but most do not, see Lemley, SSOs, supra note 3 , and it is often impractical for a patentee to make that judgment as the standard is being set, since many patents will not yet have issued and their claims may change over time. 
implementation of the standard itself infringes is necessarily arguing that the patent is essential to the standard. ${ }^{61}$ A patentee who successfully denies its patent is essential to the standard should have a hard time then persuading a court that a product infringes simply because it complies with that standard. ${ }^{62}$ Conversely, a defendant that successfully compels arbitration over a patent should not be permitted to deny in that arbitration that its compliant product infringes that patent.

One particular species of under-declaring has to do with patent applications and other yet-to-be-patented inventions. It seems clear that the FRAND obligation should extend not just to issued patents but to pending patents as well, ${ }^{63}$ and we urge SSOs to make that explicit. ${ }^{64}$ Inventors can keep patent applications pending in the PTO for years or even decades and can even seek additional new patents from old applications, ${ }^{65}$ and the PTO takes years to issue a patent. ${ }^{66}$ It would make little sense to limit a FRAND commitment only to those patents that happen to have issued by the time the standard is adopted. And while the scope of patent claims can certainly change during prosecution, so that we might not know at the outset whether a particular patent was essential to the standard, as noted, supra, we don't need to know exactly which patents are essential to include them in the FRAND commitment.

We would apply the same analysis to an idea developed at the time a standard issues but not yet the subject of a patent application. For an invention to be essential to a technical standard, it presumably must have been made at the time that standard is adopted. With limited exceptions, an inventor with an idea essential to a technical standard must file an application within one year after adoption of the standard or lose rights to the invention under the statutory bars. ${ }^{67}$ Accordingly, we suggest that SSOs specify that the

61. Fujitsu Ltd. v. Netgear Inc., 620 F.3d 1321, 1327 (Fed. Cir. 2010) (allowing owner of a standard-essential patent to show infringement by showing the defendant complied with the standard).

62. See Apple, Inc. v. Samsung Elecs. Co., 695 F.3d 1370, 1374 (Fed. Cir. 2012) (requiring a causal nexus between infringement and sales for injunctive relief).

63. See Lemley, supra note 3, at 1958 (making this argument).

64. Some already do so. See id. at 1904-11; Bekkers \& Updegrove, supra note 3, at 4445 (identifying SSOs that apply FRAND policies to patent applications).

65. See, e.g., Mark A. Lemley \& Kimberly A. Moore, Ending Abuse of Patent Continuations, 84 B.U. L. Rev. 63, 72-80 (2004).

66. See John R. Allison \& Mark A. Lemley, Who's Patenting What? An Empirical Exploration of Patent Prosecution, 53 VAND. L. REV. 2099, 2118-21 (2000) (finding that the average patent takes 2.77 years to issue).

67. The America Invents Act changed the definition of prior art, but if anything it shortened the grace period an inventor is allowed before filing. See 35 U.S.C. \102 (2012). 
FRAND commitment applies not only to existing patents and applications but also-at the very least- to those applications filed within one year after the SSO adopts the standard. ${ }^{68}$

\section{Reciprocity}

A patentee that makes a FRAND commitment to an SSO covering a particular standard may reasonably expect that others with essential patents covering the same standard will make the same commitment. Under our proposal, therefore, a FRAND offer to a party that owns standard-essential patents can be made conditional on the would-be licensee itself making a reciprocal FRAND offer. By definition, that offer must cover the would-be licensee's portfolio of standard-essential patents reading on the same standard.

When the would-be licensee is a member of the same SSO, as will often be the case since those with patents that read on a standard often participate in the SSO that sets that standard, we don't need any special rule or mechanism to make this happen. Each party will have made the FRAND commitment, and each party is bound by their commitment. If one party tries to go back on that commitment, the other can simply move to compel arbitration, and that should be their remedy. There is no need for defensive suspension of the FRAND commitment in this circumstance.

By contrast, when a potential licensee also owns patents essential to the same standard but has not made a FRAND commitment to the SSO, the patentee can find itself in an unfair position: threatened with injunctive relief over the standard but unable to respond in kind. Thus, we think it makes sense to permit the patent owner to require reciprocity by other essential patent owners who did not participate in the SSO and thus did not themselves make a FRAND commitment. In this circumstance, defensive suspension helps protect SSO members from holdup by non-members and encourages participation in the FRAND commitment and perhaps the SSO itself.

Defensive suspension also helps resolve another thorny issue: SSO members who make a commitment to license their patents on FRAND terms and then later acquire different standard-essential patents from a third party who made no similar commitment. We suggest in Section I.C.4 that the

68. We favor applying the FRAND commitment to all future applications filed by the party making that commitment. However, for applications filed much later, the danger of the implementer gaming the system by claiming that a subsequent patent is a standard-essential patent may exceed the danger of the patentee gaming the system by obtaining a truly essential patent not subject to the FRAND commitment. 
FRAND commitment should run with the patent; applying that position consistently would lead to the conclusion that the newly-acquired standardessential patents are not subject to the FRAND commitment. While this might seem troubling, since it allows a patentee to make a FRAND commitment and later acquire standard-essential patents that avoid that commitment, the fact is that those standard-essential patents would not have been subject to that commitment in anyone else's hands. The fact that the acquirer participated in the SSO shouldn't change that result. In any event, if the FRAND commitment is subject to defensive suspension, acquiring patents becomes much less of an issue: a party that acquires and asserts nonFRAND-encumbered standard-essential patents can expect to be sued for injunctive relief and damages by a FRAND patentee invoking its defensive suspension rights.

Whether defensive suspension can extend beyond patents essential to the standard at issue is a harder question. If an implementer has a patent essential to a different standard that ends up in the same product, and that standard is not promulgated by an SSO that requires a FRAND commitment following our best practices, the patentee who has made a commitment will be at a disadvantage. ${ }^{69}$ And if the effect of such a provision was to encourage more reciprocal FRAND commitments the world would probably be a better place. On the other hand, extending defensive suspension too far would undo the benefits of the FRAND commitment. A patentee is not entitled to demand that no one assert any patents in any field against it as a condition of following through on its FRAND commitment. ${ }^{70}$ And it is at least as plausible that an overbroad defensive suspension clause would end up nullifying FRAND commitments as that it would induce reciprocal ones. While the issue is not free from doubt, we think that an offer made conditional on the would-be licensee licensing any patents other than standard-essential patents reading on the standard at issue is not a FRAND offer. This approach also has the benefit that it does not require affirmative

69. Thus, we sympathize with the plight of Google-Motorola, which was investigated for antitrust violations for suing to enforce its patents only in response to having its Android operating system challenged in patent suits by Apple and Microsoft. Motorola Mobility LLC, No. 121-0120, 2013 WL 124100 (F.T.C. Jan. 3, 2013). But the fact that Motorola made a FRAND commitment and Apple and Microsoft didn't means the situations are not the same. See Thomas H. Chia, Note, Fighting the Smartphone Patent War with RAND-Encumbered Patents, 27 BERKELEY TECH. L.J. 209 (2012).

70. See News Release, Fed. Trade Comm'n, FTC Accepts Settlement of Charges Against Intel (Mar. 17, 1999), http://www.ftc.gov/opa/1999/03/intelcom.shtm (settling antitrust claim based on refusal to share intellectual property with any company that sued Intel seeking an injunction). 
action by each patentee. The SSO can simply provide that a FRAND commitment can be suspended as to any party that holds essential patents covering the same standard who is not willing to make the same commitment. ${ }^{71}$

\section{Transfer of Standard-Essential Patents}

The FRAND obligation should travel with the patent. The economic case for this is overwhelming. The very point of the commitment is to comfort implementers that they will not be held up by parties refusing to license patents essential to the standard. ${ }^{72}$ If a patentee can undo the FRAND commitment merely by selling its patents to someone who has not personally made that commitment, that comfort is illusory. ${ }^{73}$ Large technology companies have increasingly turned to "patent privateering" in an effort to raise money or to raise rivals' costs, selling part of their portfolios to patent assertion entities to enforce those patents against others in the industry. ${ }^{74}$ Nokia has spun out patents to Mosaid to use against its rivals; Micron has sold thousands of patents to patent assertion entities, and so on. ${ }^{75}$

Fortunately, this is a relatively easy problem for SSOs to solve with suitably crafted patent rules. These rules should prevent a patentee from avoiding or weakening its FRAND commitment merely by selling encumbered patents. Patent law has previously encountered the problem of people who try to sell the same right twice, and the general rule is that if you transfer all or part of a right to one party and record that transfer with the patent office, any subsequent buyer takes subject to that restriction even if

71. One implication of our approach is that most open source licenses will not be FRAND compliant because they condition a license on things beyond reciprocal licensing of standard-essential patents. Cf. Greg Vetter, Patenting Cryptographic Technology, 84 CHI.-KENT L. REV. 757, 774 (2010) (noting that open-source advocates oppose RAND in favor of royaltyfree or, better still, viral patent licensing); Jason Schultz \& Jennifer M. Urban, Protecting Open Innovation: The Defensive Patent License as a New Approach to Patent Threats, Transaction Costs, and Tactical Disarmament, 26 HARV. J. L. \& TECH. 1 (2012) (proposing an open-source viral patent license).

72. See supra text accompanying note 11 .

73. In fact the comfort can only ever be partial, because there is no way to assure that there are no parties out there who don't belong to the SSO and will pop up claiming to own an essential patent. But if the major industry players participate in the SSO, that risk is at least minimized.

74. For discussions of privateering, see, for example, Tom Ewing, Indirect Exploitation of Intellectual Property Rights by Corporations and Investors, 4 HASTINGS SCI. \& TECH. L.J. 1 (2012); Lemley \& Melamed, supra note 17.

75. Lemley \& Melamed, supra note 17; Andrei Hagiu \& David B. Yoffie, The New Patent Intermediaries: Platforms, Defensive Aggregators, and Super-Aggregators, 27 J. ECON. PERSP. 45 (2013). 
they didn't know about it. $^{76}$ Put another way, after recordation there is no bona fide purchaser for value doctrine in patent law. ${ }^{77}$ So the solution to the problem is easy if we think of a FRAND commitment as an executory license without a price term, rather than a mere promise to license in the future. $^{78}$ But even if we don't, the law can and should treat a binding commitment to license a patent to all comers as something that encumbers the patent itself, so that merely selling the patent cannot release the commitment. ${ }^{79}$ Just as a mendacious patentee can't whitewash inequitable conduct by selling the patent to someone who didn't lie to the patent office, ${ }^{80}$ a patentee that has promised that a patent will not be enforced by means of an injunction can't wipe away that commitment by finding a buyer who didn't make that promise. While we think patent or antitrust law would find their way to that result if need be, ${ }^{81}$ the SSO could help matters along by making clear that a patentee's FRAND commitments bind not only itself but also its successors, and by keeping a record of the FRAND commitments it receives and making them available to willing licensees. Coupled with an accurate and up-to-date PTO database of patent assignments, it should be straightforward for a willing licensee to determine whether a patent is owned by a company that made a FRAND commitment.

Once we understand that a FRAND commitment travels with the patent, many of the complexities around transfer fall away. Patentees will have no incentive to sell off part of a FRAND-encumbered portfolio to privateers to evade their FRAND commitment. Legitimate transactions may leave

76. See 35 U.S.C. $\int 261$ (2012). But see Board of Trustees of Leland Stanford Jr. Univ. v. Roche Molecular Sys., 131 S. Ct. 2188 (2011) (finding an exception to this rule). Stanford dealt with a situation in which the Court concluded there was no transfer of the right to the first acquirer because the contract with Stanford only promised to later assign patents, rather than actually operating to assign them. $I d$. at 2197. Treating a FRAND commitment as an executory license would solve this problem, though if SSOs take our approach it is not necessary.

77. See 35 U.S.C. $\int 261$.

78. For an argument that we should do just that, see Lemley, supra note 3, at 1914-16.

79. For an argument that this is permissible under the law of servitudes, see Jay Kesan, FRAND's Forever: Standards, Patent Transfers and Licensing Commitments, IND. L.J. (forthcoming 2013), available at http:/ / ssrn.com/abstract $=2226533$.

80. See, e.g., 1st Media, LLC v. Elec. Arts, Inc., 694 F.3d 1367, 1369-72 (Fed. Cir. 2012) (considering inequitable conduct claim even though inventor accused of inequitable conduct was no longer the patent owner).

81. Implied license or equitable estoppel doctrines might limit enforcement of such a patent. See Mark A. Lemley \& David McGowan, Could Java Change Everything? The Competitive Propriety of a Proprietary Standard, 43 AnTITRust BulL. 715 (1998). Alternatively, the Federal Trade Commission has shown a willingness to rely on Section 5 of the FTC Act to prevent fraudulent conveyances like this. See Negotiated Data Solutions LLC (N-Data), No. C-4234, 2008 WL 4407246 (F.T.C. Sept. 22, 2008). 
standard-essential patents in different hands, but there is no reason to think they will change the process we have described, supra, or the royalty rate the patents will command in an arbitration proceeding. A buyer may get a higher total royalty if it now owns more standard-essential patents, but the seller should get a correspondingly smaller royalty. ${ }^{82}$ And an implementer who has already paid for a license to a patent does not need to pay again for that patent just because it was sold, though of course the implementer may have to pay to license different patents from the buyer.

\section{SIMPLIFYING THE FRAND DEBATES}

Much of the time and effort that has been spent by courts and commentators in the FRAND debate seems misdirected. Many of the contested issues are sideshows that become moot under our proposals. Here are some important examples.

\section{A. BREACH OF FRAND COMMITMENT}

Parties have spent a great deal of time litigating the question of whether one or both sides have breached a FRAND commitment. Implementers argue that patentees' offers to license are not really reasonable, and thus breach the patentees' commitment to license on FRAND terms. Patentees argue that implementers are not negotiating in good faith and therefore are infringers rather than putative licensees working to figure out the right royalty payment. ${ }^{83}$ Courts are asked to resolve what constitutes a breach of the FRAND commitment. Doing so necessarily requires the court to make a substantive judgment regarding what is a reasonable royalty, and then a second judgment of whether one or both parties' offers were reasonably close to a reasonable royalty. ${ }^{84}$ And it blurs the line between settlement

82. Disaggregating patent rights to try to artificially increase the total royalty is socially costly. See Lemley \& Melamed, supra note 17, at 30 (discussing the ways disaggregation can increase the Cournot Complements problem, reducing the efficiency of patent licensing). Disaggregation to evade a FRAND commitment should be discouraged or prevented by SSO patent rules. This is one reason why it is desirable, in principle, that the reasonable royalty rate for a standard-essential patent portfolio equal the sum of the reasonable royalties for the individual patents in that portfolio, as noted, supra text accompanying note 52 . If that "neutrality principle" applies, a patent owner has no incentive based on the FRAND regime to sell its portfolio to a third party or split up its portfolio.

83. See Microsoft Corp. v. Motorola, Inc., 696 F.3d 872, 878 (9th Cir. 2012); Apple, Inc. v. Motorola Mobility, No. 11-CV-178-BBC, 2012 WL 5416941, at *1-2 (W.D. Wisc. Oct. 29, 2012); Microsoft Corp. v. Motorola, Inc., 864 F. Supp. 2d 1023, 1033-36 (W.D. Wash. 2012).

84. See Microsoft, 864 F. Supp. 2d at 1036-39. 
negotiations and litigation in ways that may give parties pause before entering into candid pre-litigation license negotiations.

Our response to this debate is simple: who cares? The fight over breach of the FRAND commitment occurs because implementers have claimed that a standard-essential patent holder has failed to make a FRAND offer, and thus is in breach and cannot seek an injunction, perhaps due to patent misuse. Patentees counter by saying the implementer acts in bad faith and so loses the benefit of the license. But if injunctions are generally off the table, this argument becomes moot. Under our proposal, if an implementer thinks an offer is not FRAND, the implementer can just say "no." If the standardessential patent holder does not want to budge, they go to arbitration to determine what is FRAND. There is no need to have a preliminary assessment of whether the offer was FRAND or close enough to FRAND.

Several other legal concerns also melt away under our proposal. If the parties have a mechanism in place to determine a reasonable royalty and bind the parties to that judgment, we no longer need to litigate whether the patentee's commitment creates an implied license, promissory estoppel, or equitable estoppel, and whether it is intended to benefit third parties. Our approach also sweeps away all the discussion of whether an offer was "so unreasonable" as to constitute a breach of the FRAND commitment. ${ }^{85}$ This includes not only seeking "excessive royalties" but also "coercing" a license to non-standard-essential patents in exchange for standard-essential patents, or simply seeking an injunction. ${ }^{86}$ All this is moot. The only question courts need to ask is whether each party agreed to participate in the arbitration and be bound by the results. If so, it doesn't matter how reasonable or unreasonable their negotiating position was.

\section{B. DEClaratory JUDGMENTS}

Implementers sometimes seek declaratory judgments regarding what is FRAND or finding that an offer was not FRAND. ${ }^{87}$ This becomes unnecessary under our proposed regime. If you want a decision on what a FRAND royalty rate is, go to arbitration.

As noted, supra, while a court can and will compel a patentee to arbitrate, there is no legal way to compel an implementer who wants to resolve the question in court to go to arbitration if they refuse. ${ }^{88}$ But what SSOs can and

85. Id. at 1038 .

86. Id.

87. See, e.g., Complaint at 21, Microsoft Corp. v. Motorola, Inc., No. C10-1823JLR, (W.D. Wash. 2013), 2010 WL 4466798.

88. Supra Section I.C.1. 
should do in that situation is release the patentee from the FRAND commitment not to seek an injunction. An implementer who wants to challenge the validity or infringement of the patents is free to do so in court, but if they are not willing to pay a FRAND royalty, they shouldn't benefit from the patentee's forbearance in seeking damages and injunctive relief. That won't make declaratory judgments of invalidity impossible, but should make them rare.

Implementers may try a different strategy: agree to arbitration, pay the royalty set by the arbitrator, and then file suit later to try to invalidate the patent. Under MedImmune v. Genentech, licensees have the power to go to court to challenge the validity of a patent even if they promised in the license agreement they wouldn't. ${ }^{89}$ In effect, they can take advantage of the patentee's license offer and still challenge the validity of the patent without fear of consequences - at least, consequences for that license deal. ${ }^{90}$ The same is true today with standard-essential patents: an implementer that takes a license to a standard-essential patent is free to challenge the validity of that patent by declaratory judgment in court, or to seek reexamination of the patent in the PTO. ${ }^{91}$

Reasonable minds can differ on the wisdom of this rule. It encourages challenges to validity, which are public goods that might otherwise be undersupplied by settlements. ${ }^{92}$ But the rule also makes it harder to achieve finality. In any event, two things may make such challenges less important under our approach. First, the FRAND rate negotiated or set by arbitration applies to all of the essential patents owned by an SSO participant. A declaration that a particular patent is invalid may not benefit an implementer much if the rest of the portfolio remains untouched. Second, under our approach, the arbitrator's award is based on an ex ante probabilistic assessment of the

89. See MedImmune, Inc. v. Genentech, Inc., 549 U.S. 118, 113, 137 (2007).

90. For discussion of ways patentees may be able to punish efforts by licensees to challenge patents, see Michael Risch, Patent Challenges and Royalty Inflation, 85 IND. L.J. 1003 (2010). For limits on no-challenge clauses, see, for example, Rates Technology Inc. v. Speakeasy, Inc., 685 F.3d 163 (2d Cir. 2012).

91. See MedImmune, 549 U.S. at 133, 137; In re Baxter Int'l, Inc., 678 F.3d 1357, 1360, 1364-65 (Fed. Cir. 2012).

92. See, e.g., Christopher A. Cotropia, Modernizing Patent Law's Inequitable Conduct Doctrine, 24 Berkeley TECH. L.J. 723, 752-53 (2009); Joseph Farrell \& Robert P. Merges, Incentives to Challenge and Defend Patents: Why Litigation Won't Reliably Fix Patent Office Errors and Why Administrative Patent Review Might Help, 19 BERKELEY TECH. L.J. 943, 952 (2004); Joseph Scott Miller, Building a Better Bounty: Litigation-Stage Rewards for Defeating Patents, 19 BERKELEY TECH. L.J. 667, 687-88 (2004); John R. Thomas, Collusion and Collective Action in the Patent System: A Proposal for Patent Bounties, 2001 U. ILL. L. REV. 305, 317. 
entire portfolio. That ex ante assessment necessarily assumes that some patents in the portfolio may be invalid or not infringed. So there is no reason that a subsequent finding of invalidity should change the reasonable royalty determination. Some SSOs may want to make this point explicitly in their IP rules by stating that FRAND rates established through arbitration remain in force regardless of the outcome (either way) of subsequent validity challenges to a subset of the patents in the portfolio.

Second, while MedImmune held that licensees could challenge validity, ${ }^{93}$ the same does not hold for defendants in a patent infringement suit who settle the suit by taking a license. Once a case is at issue, a settlement resolves the dispute with prejudice and the parties cannot reopen it. ${ }^{94}$ Suing a defendant and then settling, in other words, offers patentees a way around MedImmune. The same may be true of disputes resolved by arbitration, though the courts have not resolved this issue. If so, resolution of a legal dispute over the FRAND commitment by arbitration will bar further challenges to the validity of the patent, at least as they relate to that implementer practicing that patent to implement the standard. An implementer will always be able to seek ex parte reexamination of the patent, though not inter partes reexamination or post-grant opposition. ${ }^{95}$ But if they participate in the FRAND arbitration process, they are likely to be bound by the results.

\section{CONFLict Between Jurisdictions}

Different jurisdictions have very different rules regarding injunctions. Germany and the U.S. International Trade Commission, for instance, grant injunctions on different terms than do the U.S. courts after eBay. ${ }^{96}$ As a result, some patentees have turned to courts that will automatically grant injunctions, even on FRAND-encumbered standard-essential patents. ${ }^{97}$ Implementers in turn have sought to prevent resort to these courts by a variety of means, including antitrust law and anti-suit injunctions. ${ }^{98}$ This competition between jurisdictions not only creates comity concerns, but also

93. MedImmune, 549 U.S. at 118.

94. See Pactiv Corp. v. Dow Chem. Co., 449 F.3d 1227, 1230-32 (Fed. Cir. 2006); see also Aspex Eyewear, Inc. v. Marchon Eyewear, Inc., 672 F.3d 1335, 1345-46 (Fed. Cir. 2012).

95. 35 U.S.C. $\iint 317,329$ (2012) (establishing that participants in inter partes reexamination and post-grant opposition must not have litigated the validity of the same patent before).

96. eBay Inc. v. MercExchange LLC, 547 U.S. 388 (2006); Chien \& Lemley, supra note 20.

97. See, e.g., Microsoft Corp. v. Motorola, Inc., 696 F.3d 872, 879-80 (9th Cir. 2012) (describing Motorola's suit against Microsoft in Germany for patent infringement in which Motorola sought—and was granted — an injunction).

98. See, e.g., id. at 880-81; Motorola Mobility LLC, No. 121-0120, 2013 WL 124100 (F.T.C. Jan. 3, 2013). 
raises questions about whether the patentee has impliedly licensed the implementer's use, and how different jurisdictions treat implied licenses. All this becomes moot if the SSO rules are clarified as we propose. A patentee who has made a FRAND commitment has agreed to resolve all disputes via arbitration. Under U.S. law, that commitment can be enforced by sending the dispute to arbitration, regardless of where it arises. ${ }^{99}$

\section{ANTITRUST}

Another significant benefit of our approach is that it significantly reduces the need for antitrust litigation to effectuate meaningful FRAND commitments. Courts, commentators, and regulatory agencies have devoted quite a bit of attention to antitrust scrutiny of standard-essential patents over the past decade. ${ }^{100}$ Some of these cases have argued that seeking an injunction after making a FRAND commitment or failing to disclose a standard-essential patent constitutes monopolization (or attempted monopolization). ${ }^{101}$ Others have argued that SSOs create an unlawful buyer's cartel by conspiring to fix royalty rates on a patent. ${ }^{102}$

Antitrust has an important role to play where SSOs do not set clear rules or set rules that can readily be gamed. Patentees who game those lessdesirable rules by hiding information from the $\mathrm{SSO},{ }^{103}$ making unreasonable

99. Not all jurisdictions may have the same rules regarding arbitration. We think the U.S. law is particularly suitable to our approach, but we are not experts in foreign law. To ensure uniformity in implementing our approach, SSOs should specify the law that applies to the enforcement of the arbitration agreement. If they don't and if a court in a foreign jurisdiction ignores the FRAND commitment and allows a suit for injunctive relief to proceed, the most the SSO can do is permit the implementer to engage in defensive suspension of the FRAND commitment with respect to its own patents.

100. See, e.g., Microsoft, 696 F.3d 872; Rambus Corp. v. FTC, 522 F.3d 456 (D.C. Cir. 2008); Broadcom Corp. v. Qualcomm, Inc., 501 F.3d 297 (3d Cir. 2007); Apple, Inc. v. Motorola Mobility, No. 11-CV-178-BBC, 2012 WL 5416941 (W.D. Wisc. Oct. 29, 2012); Apple, Inc. v. Samsung Elec. Co., No. 11-CV-01846-LHK, 2012 WL 2571719 (N.D. Cal. June 30, 2012); Apple, Inc. v. Motorola Inc., No. 1:11-CV-08540, 2012 WL 1959560 (N.D. Ill. May 22, 2012); Microsoft Corp. v. Motorola, Inc., 864 F. Supp. 2d 1023 (W.D. Wash. 2012); Motorola Mobility LLC, No. 121-0120, 2013 WL 124100 (F.T.C. Jan. 3, 2013); Statement of the Federal Trade Commission, Robert Bosch GmbH, No. 121-0081 (F.T.C. 2013), available at http://www.ftc.gov/os/caselist/1210081/121126boschcommissionstatement.pdf; Negotiated Data Solutions LLC (N-Data), No. C-4234, 2008 WL 4407246 (F.T.C. Sept. 22, 2008); Dell Computers, Inc., 121 F.T.C. 616 (1996). The leading treatise on IP and antitrust devotes an entire chapter to the issue. HOVENKAMP ET AL., supra note 41, ch. 35.

101. Rambus Corp., 522 F.3d 456; Broadcom Corp., 501 F.3d 297; Apple v. Samsung, 2012 WL 2571719.

102. See, e.g., HoVENKAMP ET AL., supra note 41, \35.6 (collecting cases).

103. Rambus Corp., 522 F.3d 456. 
demands, ${ }^{104}$ or trying to avoid a FRAND commitment by selling the patents may face antitrust liability or other forms of government regulatory scrutiny. ${ }^{105}$ The SSO itself or its members may even face Sherman Act Section 1 antitrust exposure if the SSO rules are so vague as to facilitate patent holdup or a buyer's cartel. ${ }^{106}$ Even if the standard overall is procompetitive (that is, it generates consumer benefits), under a "least restrictive alternative" approach an SSO and its members may not be immune from antitrust scrutiny if the rules are significantly flawed in a way that creates market power for some of the members.

Under our approach, many of these issues should become moot, since the patentee cannot obtain an injunction (or transfer the patent to someone who can) against a willing licensee, and since competitors are not involved in jointly setting the reasonable royalty rate. If SSOs set clear, reasonable rules following the best practices we recommend, and parties follow those rules, there should be little or no need for antitrust to intervene. Indeed, even the risk of non-disclosure of a patent is lessened, since the patentee has committed to license its essential patents whether or not it discloses them. For the most part, the rules we have described are self-executing, meaning that even if a party tries to break the rules set by the SSO there still may be no need for antitrust to intervene. Thus, we suggest that parties who abide by these procedures-patentees, implementers, and the SSOs themselvesshould be immune from antitrust liability for activities that merely follow those rules. ${ }^{107}$ They have entered into an arrangement that is on balance good for competition, one that allows patentees to receive reasonable royalties but prevents holdup and reduces the risk of monopolization by trickery.

The fact that antitrust remains a last resort available when SSOs don't follow best practices may have two practical benefits, however. First, under our approach the promise of avoiding the risk of antitrust liability will be a powerful incentive for both SSOs and patent owners to adopt the best practices we propose. Second, the risk of antitrust liability may be relevant

104. Broadcom Corp., 501 F.3d 297.

105. N-Data, 2008 WL 4407246. N-Data was brought under the FTC's section 5 authority, which applies where an unfair trade practice harms competition without necessarily rising to the level of an antitrust violation. Notably, only the FTC, not private parties, can enforce section 5. 15 U.S.C. $\int 45$ (2012).

106. See U.S. Dep’t of Justice \& Fed. Trade Comm’n, Antitrust Enforcement and Intellectual Property Rights: Promoting InNovation and Competition, supra note 1 , at $53-56$.

107. See Thomas F. Cotter, Reining in Remedies in Patent Litigation: Three (Increasingly Immodest) Proposals, 30 SANTA ClARA COMPuTER \& High TECH. L.J. (manuscript at 4) (forthcoming 2013) (arguing that FRAND royalties are properly resolved as a matter of patent, not antitrust law). 
when an individual patentee wants to adopt best practices but the SSO governing the standard has not yet done so. We propose that a patentee that unilaterally commits to the FRAND procedures we describe here should be immune from antitrust liability for following these procedures. ${ }^{108} \mathrm{~A}$ patentee's unilateral binding commitment to arbitration could be enforced whether or not it was elicited by an SSO. Thus, just as the prospect of antitrust immunity might lure SSOs to adopt best practices, it might also lure patentees to implement those practices even if the SSO has not done so. Given the large number of standard-essential patents based on preexisting standards, ${ }^{109}$ and given that SSOs tend to update their IP rules rather slowly, ${ }^{110}$ this is not a small matter.

\section{CONCLUSION}

Most of the litigation and debate over the FRAND commitment is unnecessary. SSOs can and should adopt best practices that will prevent patentee holdup while ensuring that the question of the appropriate royalty is resolved in a fair and predictable way. True, there will still be hard questions to face, notably determining the appropriate royalty in the face of the complexities of modern technology. But we think the FRAND commitment should be understood to create a simple, binding commitment that allows the patent holders and willing licensees to resolve those difficult questions through baseball-style binding arbitration if they cannot come to terms on their own. Rarely will they need to go to court.

108. A patentee that acts unilaterally may reasonably worry more about reciprocity than those who act under the aegis of an SSO. Thus, a broader defensive suspension clause might be justifiable in this circumstance.

109. See, e.g., Lemley \& Shapiro, supra note 14 (documenting thousands of patents declared essential to just two standards).

110. Compare Contreras, supra note 5, with Lemley, SSOs, supra note 3 (studying SSO policies ten years apart). 